\title{
Control de los daños por cristalización en la caliza de Malta mediante inhibidores de sales
}

\section{Controlling crystallization damage by the use of salt inhibitors on Malta's limestone}

\author{
$\underline{\text { J. Cassar }}^{(*)}$, A. Marrocchi(**), M. L. Santarelli(***) y M. Muscat(*)
}

Recepción/Received: 14-V-07

Aceptación/Accepted: 11-I-08

Publicado online/Online publishing: 06-II-08

\section{RESUMEN}

El principal tipo de piedra para construcción existente en las islas maltesas es la caliza globigerina, de la cual suele utilizarse la capa inferior, existiendo dos tipos: la duradera franka y la soll, de meteorización más fácil. Se retiraron de una cantera dos tipos de franka (bajda -blanca- y safra -amarilla-), así como bloques de soll. La identificación, realizada por los propietarios de la cantera, fue confirmada posteriormente mediante pruebas geoquímicas. Se estudiaron las propiedades físicas y mecánicas de las tres piedras, incluidas la resistencia a la compresión uniaxial, la absorción de agua por capilaridad, la permeabilidad y la distribución del tamaño de los poros. Los resultados de la porosimetría confirmaron los resultados de diferentes investigaciones anteriores. Soll resultó tener una porosidad total inferior con un alto porcentaje de pequeños poros y prácticamente ningún poro grande. $A$ continuación, algunas de las piedras analizadas se trataron con diferentes concentraciones de disoluciones acuosas de un compuesto de fósforo orgánico no tóxico que contenía grupos funcionales carboxílicos como inhibidor de la sal, y del correspondiente compuesto no fosforilado.

Palabras clave: sales, inhibidores de la cristalización, deterioro, caliza globigerina.

\section{SUMMARY}

The main building stone in the Maltese Islands is the Globigerina Limestone, of which the Lower member is commonly used. This occurs in two types, the durable franka and the more easily weathered soll. Two types of fresh franka (bajda (white) and safra (yellow)), as well as fresh soll stone blocks, were obtained, based on the identification by quarry owners. Their designation was confirmed by geochemistry. Physical and mechanical properties of the three were investigated, including uniaxial compressive strength, water absorption by capillarity, permeability and porosimetry. Porosimetry results confirmed outcomes of previous research work. Soll was found to have a lower overall porosity, but a high percentage of small pores with practically no large pores. Some of the tested stones were then treated with a non-toxic phospho-organic compound containing carboxylic moieties as a salt inhibitor and the corresponding non-phosphorylated compound.

Keywords: salts, crystallization inhibitors, deterioration, globigerina limestone.

\footnotetext{
(*) Universidad de Malta (Msida, Malta)

(**) Universidad de Perusa (Perusa, Italia)

(***) CISTeC, Universidad de Roma La Sapienza (Roma, Italia)
} 


\section{INTRODUCCIÓN}

Las islas maltesas constan de dos islas principales, Malta y Gozo, y de algunos islotes. En ellas, la mayoría de los monumentos y de la arquitectura autóctona, así como de los edificios modernos, están construidos con la caliza globigerina local, uno de los pocos recursos naturales de las islas. Puede describirse esta piedra como una caliza blanda típica, muy fácil de esculpir y perfilar. Forma parte de la gran familia de las calizas blandas oligomiocénicas tan comunes en la cuenca mediterránea. La formación de caliza globigerina aflora principalmente en las zonas central y meridional de la isla mayor, Malta, y en la parte occidental de la isla de Gozo, de menor tamaño. En el punto de afloramiento, esta formación está estratificada en gruesas capas. Las secciones con concentración de bioturbación son frecuentes. Esta caliza, de grano fino y color entre amarillo y gris pálido, está compuesta casi en su totalidad de los esqueletos calcáreos de los foraminíferos planctónicos globigerínidos. Desde el punto de vista petrográfico, la caliza globigerina puede describirse como un packstone bioclástico con presencia de wackestones bioclásticos. La meteorización de esta piedra puede verse con frecuencia a nivel local en edificios de todas las edades en forma de distintos grados de meteorización alveolar, con pérdida de gran parte del grosor original de la piedra durante el proceso. Esto puede atribuirse a la interacción de las propiedades intrínsecas con las condiciones externas.

A pesar de que la piedra de construcción obtenida de esta formación es bastante homogénea en cuanto a su textura y color, los canteros malteses distinguen dos variedades: la duradera franka y la soll, de meteorización más acelerada. Dentro de la variedad franka existen dos tipos: la bajda (blanca) y la safra (amarilla) (1).

Las condiciones ambientales externas de las pequeñas y desprotegidas islas que forman el archipiélago maltés son especialmente duras. La cristalización de sales solubles, en particular cloruros pero también sulfatos y nitratos, se considera uno de los procesos de meteorización más importantes de cuantos contribuyen a la degradación de monumentos y yacimientos arqueológicos. El agua subterránea salina se introduce en la fábrica y las sales transportadas por el viento se asientan sobre la superficie, donde se disuelven para luego introducirse en el interior; se produce la cristalización debido a la evaporación del líquido de la disolución o a los cambios de temperatura y concentración. La cristalización de sales puede producirse tanto en la superficie de un material poroso (eflorescencia) como dentro de su sistema poroso (subeflorescencia). Aun siendo aparatosa, la eflorescencia provoca pocos daños a la piedra, la mayoría de tipo estético. La subeflorescencia, por el contrario, genera normalmente importantes daños, ya que la expansión que conlleva es

\section{INTRODUCTION}

The Maltese Islands consist of two main islands, Malta and Gozo, as well as a small number of islets. Here, most monuments and vernacular architecture, as well as modern buildings, are built of the local Globigerina Limestone, one of the few natural resources of the Islands. This stone can be described as a typical "soft limestone", very easy to carve and shape. It forms part of the large family of Oligo-Miocene "soft limestones" widely diffused in the Mediterranean basin. The Globigerina Limestone Formation outcrops mainly in the central and southern parts of the main island of Malta, and in the western part of the smaller island of Gozo. This Formation is stratified into thick beds at outcrop. Sections where bioturbation is concentrated often occur. This limestone is fine-grained, yellow to pale grey in colour, almost wholly composed of the tests of globigerinid planktonic foraminifera. Petrographically, Globigerina Limestone can be described as a bioclastic packstone, with bioclastic wackestones also occurring. Weathering of this stone can often be seen locally in buildings of all ages as varying degrees of alveolar (or honeycomb) weathering, with loss of much of the original stone thickness in the process. This can be attributed to the interaction of intrinsic properties with external conditions.

Although the building stone obtained from this Formation is fairly homogeneous in texture and colour, Maltese stone workers distinguish two varieties, the durable fran$k a$ and the more easily weathered soll. Within the franka variety, two types exist - the bajda (white) type and the safra (yellow) type (1).

The external environmental conditions in the small, exposed Islands which make up the Maltese archipelago are particularly harsh, with the crystallization of soluble salts, in particular chlorides but also sulphates and nitrates, being acknowledged as one of the most important weathering processes contributing to the decay of monuments and archaeological sites. Saline groundwater migrates into masonry, and wind blown salts settle on the surfaces and then migrate inwards in solution; salts crystallize due to solution evaporation or changes in temperature and concentration. The process of salt crystallization can take place both on the surface of a porous material (efflorescence) and within the porous system (subefflorescence). The former, while appearing impressive, results in little damage to the stone and this is mostly aesthetical. The latter, on the other hand, typically creates extensive damage as the associated expansion is enough to disrupt the internal structure and cause loss of surface. Physical and chemical properties of stone will determine the degree and 
suficiente para deteriorar la estructura interna y provocar la pérdida de material en la superficie. Las propiedades físicas y químicas de la piedra determinarán el grado y el tipo de deterioro (pulverización, exfoliación, desprendimiento de costras, etc.) que sufrirá ésta.

A pesar de las exhaustivas investigaciones sobre el desarrollo de protocolos que impidan o reduzcan los daños causados por la cristalización, aún no existen métodos específicos de conservación eficaces. Esto se debe a los datos e interpretaciones contradictorios sobre las causas de la degradación provocada por las sales, la forma en que los cristales crecen en los poros y la manera en que una sal actúa en combinación con otras. En el pasado se ha intentado controlar los daños provocados por las sales en la piedra porosa mediante la desalinización. Normalmente se intenta retirar la sal mediante el uso de emplastos, pero este procedimiento sólo permite reducir los niveles de sal en la superficie de la roca o inmediatamente por debajo de ella. Por tanto, el tratamiento tiene que realizarse repetidas veces, aumentando de este modo los costes de conservación. También resulta ineficaz cuando no se elimina el origen de las sales, tarea que suele resultar imposible, por lo que las técnicas clásicas de desalinización no son adecuadas para la conservación a largo plazo. Además, no es factible para edificios o zonas arqueológicas grandes. Otras técnicas son bastante invasivas, como practicar huecos en la base del muro para aumentar la zona de evaporación y frenar la subida por capilaridad de agua rica en sales desde el suelo. Además de destructivo, este procedimiento es difícil de aplicar en yacimientos arqueológicos por su sensibilidad, la presencia de materiales generalmente muy porosos y la gran extensión de las superficies expuestas. Se conocen varios ejemplos de la ineficacia de esta técnica. Una de ellas es el yacimiento de Mohenjo Dharo (Paquistán), en el que aumentó el proceso de deterioro en vez de reducirlo.

Actualmente existe un interés creciente por el empleo de inhibidores de la cristalización respetuosos con el medio ambiente y no invasivos como una nueva forma de controlar los daños provocados por la cristalización dentro de las piedras porosas. Este artículo trata de un reciente proyecto de investigación sobre la aplicación de estos nuevos métodos no destructivos para evitar y controlar el crecimiento de cristales en piedras porosas. Se prestó especial atención a las propiedades inhibidoras de la cristalización de compuestos orgánicos con grupos funcionales, en concreto un compuesto de fósforo orgánico con grupos carboxílicos y el correspondiente grupo no fosforilado. Estos productos son solubles en agua o alcohol y no son tóxicos, por lo que son de utilización segura durante las obras de conservación. Estos compuestos se ensayaron en probetas de los principales tipos de caliza globigerina (franka -bajda y safra- y soll) recientemente extraídas de la cantera, para controlar el crecimiento de cristales de sulfato sódico. type (powdering, exfoliation, crust detachment etc.) of deterioration it will then undergo.

Despite the extensive research on the development of protocols to prevent and/or reduce salt crystallization damage, there are no specific effective methods of conservation yet. This is due to contradictory data and interpretations as to why salt decay occurs, how crystals grow in pores and how one salt acts in combination with others. In the past, desalination had been attempted to control salt damage in porous stone. The removal of salts is usually attempted through the use of poultices, but this procedure allows only the reduction of salt levels on the surface of masonry or immediately below it. The treatment has therefore to be repeated, thus increasing conservation costs. It also proves to be useless when the source/s of the salts is/are not eliminated, often an impossible undertaking. Thus, classical desalination techniques are not suitable for long-term conservation. Moreover this is not feasible for large buildings and/or archaeological areas. Other techniques are rather invasive, such as cutting the masonry at the base, thus increasing the evaporation area and reducing the salt-rich water capillary rise from the ground. Besides being destructive, this procedure is hardly applicable to archaeological sites, due to their sensitivity, the presence of often highly porous materials and to the great exposure of the surfaces. Several examples of the ineffectiveness of this technique are known. One in particular is the site of Mohenjo Dharo (Pakistan) which was cut, leading to an increase rather than to a reduction of the deterioration process.

Nowadays there is an increasing interest towards the use of environmental-friendly, non-invasive crystallization inhibitors as a new means of controlling crystallization damage within porous stones. This paper deals with a recent research project on the application of these new non-destructive methods to prevent and/or to control crystal growth in porous stones. In particular, attention has been focused on the crystallization inhibition properties of functionalised organic compounds, in particular a phospho-organic compound containing carboxylic moieties as well as the corresponding non-phosphorylated one. These products are soluble in water or alcohol and are non toxic. Their use thus ensures safety during conservation works. These compounds were tested on the main types of Globigerina Limestone, franka (bajda and safra) and soll, using fresh quarry samples, tested to control sodium sulphate crystal growth. 


\section{HISTORIA DE LOS INHIBIDORES DE SALES}

Actualmente existe un interés creciente en la utilización de inhibidores de la cristalización para controlar los daños provocados por las sales en las piedras porosas. Dado que en muchos casos no es factible impedir que la solución cristalizante se introduzca en la piedra, es fundamental impedir o reducir la nucleación y el crecimiento de los cristales.

Se sabe que los aditivos, tanto los orgánicos como los inorgánicos, desempeñan una importante función como inhibidores de los procesos de cristalización. Se cree que los inhibidores actúan principalmente de dos maneras $(2-4)$ :

1. impidiendo o retrasando la formación de núcleos estables, deteniendo de este modo la precipitación de sales;

2. modificando el hábito mediante la absorción en caras concretas de un cristal en crecimiento, reduciendo de este modo su velocidad de crecimiento.

Los inhibidores se diseñan para formar un número suficiente de enlaces coordinados con los cationes de la superficie del mineral, lo que les permite estar activos incluso si sólo existen trazas de ellos, es decir, si sólo están presentes en una cantidad insuficiente para reducir de manera significativa la sobresaturación mediante la coordinación de los cationes en disolución. Antes de que un inhibidor se adhiera a la superficie del cristal tiene que ser atraído hacia ésta. Dicha atracción puede lograrse mediante la interacción de los aniones de carga negativa del propio inhibidor con los cationes de la superficie. Es por tanto necesaria al menos una ligera ionización de los grupos funcionales del inhibidor. Sin embargo, la carga iónica no es el único factor que determina la potencia inhibidora de las moléculas: la relación espacial entre los grupos funcionales y la estructura general de las moléculas (p. ej. la presencia de tipos específicos de grupos funcionales) también desempeña un papel determinante.

Los autores del presente artículo han emprendido recientemente un proyecto de investigación (5-8) sobre el desarrollo de nuevos métodos no destructivos para evitar y controlar el crecimiento de cristales en piedras porosas. Este proyecto se basa en la aplicación de sistemas inhibidores respetuosos con el medio ambiente y no invasivos que son adecuados en distintas situaciones. Se está prestando especial atención a las propiedades inhibidoras de la cristalización de compuestos orgánicos con un número y topo adecuados de grupos funcionales.

En la literatura (9-12) existen algunos ejemplos de moléculas orgánicas que actúan como inhibidores de la crista-

\section{HISTORY OF SALT INHIBITORS}

Nowadays there is an increasing interest in crystallization inhibitors as a new means of controlling salt damage in porous stones. As in many cases it is not feasible to prevent the access of the crystallizing solution, it is therefore essential to prevent and/or to reduce the nucleation and growth of crystals.

Both organic and inorganic additives are known to play an important role as inhibitors in crystallization processes. Inhibitors are considered to act in two main ways (2-4):

1. preventing or delaying the formation of stable nuclei thus keeping salt precipitation from occurring

2. modifying habit by absorption on specific faces of a growing crystal, thus decreasing their growth rate.

The inhibitors are designed to form a sufficient number of coordinative bonds with the cations of the mineral surface; this allows them to be active even if present only in traces, that is, in an amount which is unable to significantly lower the supersaturation by coordination of the cations in solution. Before an inhibitor is bound to the crystal surface, it has to be first attracted to it. Such attraction can be provided by the interaction of the negatively charged anions of the inhibitor itself with the cations at the surface. At least some ionisation of the inhibitor functional groups is therefore needed. However, the ionic charge is not the only factor in determining the inhibitory power of the molecules: the spatial relationship between the functional groups and the whole structure of the molecules (e.g. the presence of specific types of functional groups) also plays a key role.

Recently (5-8), the present authors have undertaken a research project on the development of new non-destructive methods to prevent and/or to control crystal growth in porous stones. This project is based on the application of environmental-friendly, non-invasive inhibitor-systems, which are suitable for different cases of conservation. In particular, attention is being devoted to the crystallization inhibition properties of properly functionalised organic compounds.

A few examples of organic molecules acting as crystallization inhibitors in porous materials are already known in 
lización en materiales porosos. Basándose en la teoría sobre la acción de los inhibidores, se han identificado varios compuestos orgánicos que contienen grupos carboxilo en su estructura molecular. En el presente artículo se informa del efecto inhibidor de un compuesto de fósforo orgánico con grupos funcionales carboxílicos (inhibidor A) en comparación con el correspondiente compuesto no fosforilado (inhibidor B). Estos productos son solubles en agua o alcohol, no son tóxicos y son fáciles de aplicar, lo que permite utilizarlos de conformidad con la normativa sobre el control de emisiones de compuestos orgánicos volátiles (COV) y garantiza la seguridad durante las obras de conservación.

\section{EXPERIMENTAL}

\subsection{Caracterización de la caliza globigerina no meteorizada}

Se extrajeron muestras de caliza globigerina, tanto de soll como de los dos tipos de franka de uso común (bajda y safra), de frentes de cantera nuevos. De cada tipo de piedra se obtuvieron doce bloques. El tipo de piedra seleccionado fue determinado por los propietarios de la cantera, que por lo general son capaces de identificar los tipos de piedra de sus propias canteras (1).

Se confirmó la identificación de las muestras de franka (tanto safra como bajda) y soll mediante geoquímica, sometiendo ttresmuestras de cada tipo de piedra a la prueba del residuo insoluble en ácido (13). Se estudiaron las propiedades físicas y mecánicas de las tres piedras, incluidas la resistencia a la compresión uniaxial, la absorción de agua por capilaridad, la permeabilidad y la distribución del tamaño de los poros. En la medida de lo posible se emplearon procedimientos de ensayo estándar o recomendados, entre ellos los del BS EN 1926:1999 para el ensayo de compresión uniaxial (14), que se realizó sobre probetas cúbicas secas de $50 \mathrm{~mm}$ de lado de los tres tipos de piedra.

Para estudiar las propiedades relacionadas con la estructura porosa se usaron ensayos como la porosimetría por intrusión de mercurio y la absorción de agua por capilaridad. La distribución del tamaño de los poros en las muestras se estudió según lo establecido en la norma NORMAL 4/80 (15). El método empleado para evaluar la absorción de agua por capilaridad se basó en la norma UNI 10859:2000 (16).

\subsection{Aplicación de los inhibidores de sales y halo- clastia}

Se probaron ambos compuestos (el inhibidor A y el inhibidor B) para controlar el crecimiento de cristales de sul- the literature (9-12). On the basis of the inhibitor action theory, a number of organic compounds containing carboxyl-groups in their molecular skeleton have been identified. Herein, the inhibitory effect of a phospho-organic compound containing carboxylic moieties (inhibitor A) compared with the corresponding non-phosphorylated one (inhibitor $B$ ) is being reported. These products are soluble in water or alcohol, non toxic and easy to apply, enabling their use in accordance with the VOC (Volatile Organic Compounds) emission control and safety during conservation works.

\section{EXPERIMENTAL}

\subsection{Characterization of unweathered globigerina limestone}

Samples of globigerina limestone, including soll and the two commonly used types of franka (safra and bajda), were obtained from fresh quarry faces. Twelve stone blocks were obtained for each stone type. The type of stone selected was determined by the quarry owners, who are usually able to identify stone types in their own quarry (1).

The designation of franka (both safra and bajda) and soll samples was confirmed by geochemistry, using an acid insoluble residue test (13), where three samples from each stone type were tested. The physical and mechanical properties of the three types were investigated. These included uniaxial compressive strength, water absorption by capillarity, permeability and porosimetry. Whenever possible, standard or recommended testing procedures were used; these included BS EN 1926: 1999 for the uniaxial compression test (14), carried out on dry $50 \mathrm{~mm}$ cubes of the three types of stone.

Tests to investigate properties related to the pore structure included mercury intrusion porosimetry and water absorption by capillarity. The pore size distribution of the samples was investigated using Normal 4/80 (15). The method used for the evaluation of water absorption by capillarity suction was based on UNI 10859:2000 (16).

\subsection{Application of salt inhibitors and salt weathe- ring}

The two compounds (inhibitor $A$ and inhibitor $B$ ) were tested to control sodium sulphate crystal growth in soll, 
fato sódico en probetas de caliza globigerina soll, safra y bajda. En los materiales porosos, el sulfato sódico ha resultado ser una de las sales solubles más dañinas, razón por la que es la primera estudiada en esta investigación. Actualmente se están realizando otros ensayos con $\mathrm{NaCl} / \mathrm{NaHCO}_{3}$.

Se utilizaron probetas prismáticas de $50 \times 50 \times 120 \mathrm{~mm}$, excepto para la soll, en la que el tamaño de $20 \times 20 \times 120$ $\mathrm{mm}$ venía impuesto por el de las losas disponibles. Se ensayaron cuatro probetas sin tratar de cada tipo de caliza globigerina como referencia. Cada inhibidor se disolvió en agua a una concentración muy baja (1 y 10 ppm).

Las probetas de piedra se secaron en un horno a $60{ }^{\circ} \mathrm{C}$ hasta conseguir un peso constante y luego se humedecieron por capilaridad con soluciones acuosas de los inhibidores. Posteriormente se secaron lentamente durante una semana a $25^{\circ} \mathrm{C}$ y $50 \%$ de HR hasta alcanzar un peso constante de nuevo.

Los ensayos de cristalización de sales se realizaron en cámaras con ambiente controlado $\left(23 \pm 2{ }^{\circ} \mathrm{C}\right.$, humedad relativa del $33 \pm 5 \%)$. Se vertió la disolución de sulfato sódico $(0,35 \mathrm{M})$ en un vaso de precipitados de vidrio en el que se habían colocado, en posición vertical, las probetas de caliza globigerina. La superficie de la disolución salina se selló con cera fundida para evitar su evaporación y para impulsar su subida por capilaridad por las probetas de piedra. Como consecuencia de la subida por capilaridad, se produce la evaporación del agua de la disolución salina a través de la superficie no sumergida de la piedra, resultando en la cristalización de la sal. La velocidad de evaporación del agua se midió pesando el conjunto de probeta, disolución y vaso de precipitados con una periodicidad regular.

El crecimiento de la eflorescencia y los daños consiguientes en la superficie de la caliza se registraron mediante fotografías. Los daños causados en la superficie se evaluaron también pesando el detrito eliminado de la superficie, previa separación de la sal. Por otra parte, se analizó el interior de las probetas con un microscopio digital OLYMPUS MIC-D. Para los análisis químicos se empleó un microscopio electrónico de barrido (MEB) Philips XL 30 con EDS DX-4i de Edax (detector: unidad detectora compacta de Edax).

\section{RESULTADOS Y DISCUSIÓN}

\subsection{Caracterización de la caliza globigerina no meteorizada}

A pesar del reducido número de muestras que se emplearon para la prueba de residuo insoluble en ácido y de safra and bajda Globigerina Limestone specimens. Among soluble salts in porous materials, sodium sulphate has been found to be particularly damaging, which is why it has been studied first in this research. Besides these, other tests using $\mathrm{NaCl} / \mathrm{NaHCO}_{3}$ are currently also under way.

Specimens of $50 \times 50 \times 120 \mathrm{~mm}$ were used, except for the soll (20x20x120 mm, imposed by the size of available slabs). Four blank specimens for each type of Globigerina Limestone were used as reference. Each inhibitor was dissolved in water to form two solutions at very low concentration (1 and 10 ppm).

The stone specimens were dried in an oven at $60^{\circ} \mathrm{C}$ to constant weight, and then wet by capillarity with aqueous solutions of the inhibitors. They were then slowly dried for one week at $25^{\circ} \mathrm{C}$ and $50 \% \mathrm{RH}$ to constant weight.

The salt crystallization tests were carried out in chambers with a controlled environment $\left(23 \pm 2{ }^{\circ} \mathrm{C}, 33 \pm 5 \%\right.$ relative humidity). The sodium sulphate solution (0.35M) was poured into a glass beaker where Globigerina Limestone slabs were placed vertically. The surface of the saline solution was sealed with melted wax, both to avoid excessive solution evaporation and to promote its capillary rise through the stone specimens. As a consequence of the capillary rise, water evaporation from the saline solution through the exposed surface of the stone slabs occurs, thus leading to salt crystallization. The water evaporation rate was measured by weighing the specimensolution-beaker system at regular intervals.

The salt efflorescence growth and the eventual limestone surface damage were photographically recorded. The surface damage was evaluated also by weighing the debris brushed off the surface, after separating it from the salt. The specimens were also internally analysed by OLYMPUS MIC-D digital microscope. Chemical analysis was performed using a Scanning Electron Microscope (SEM) (Philips XL 30) with EDS Edax DX-4i (detector: Edax $C D U)$.

\section{RESULTS AND DISCUSSION}

\subsection{Characterization of unweathered Globigerina Limestone}

Despite the limited amount of samples used for the acidinsoluble residue test, and some inhomogeneities due to 
ciertas faltas de homogeneidad debidas a la naturaleza de la piedra, se confirmó que la soll identificada por los propietarios de la cantera y obtenida para los ensayos era soll (7,03\% de residuos insolubles) y que las muestras de bajda y safra eran franka $(2,07 \%$ y $2,29 \%$ de residuos insolubles de media, respectivamente). Hasta la fecha se han obtenido para franka y soll unas variaciones de $1-3 \%$ y $3-14 \%$, respectivamente (13).

Los resultados de las pruebas físicas y mecánicas de estas muestras confirmaron las investigaciones previas al respecto. Así, la media más elevada de resistencia a la compresión en seco se obtuvo para las muestras de soll, seguida de las de bajda y safra (franka), como se muestra en la tabla 1. Por otra parte, las resistencias a la compresión uniaxial de estas últimas, ambas franka, eran equiparables. Estos resultados concuerdan con las investigaciones realizadas anteriormente por Cachia (17), en las que la soll resultó tener una mayor resistencia a la compresión que la franka, con un valor promedio de $32,9 \mathrm{~N} / \mathrm{mm}^{2}$. Una posible razón para que la resistencia a la compresión sea mayor en las muestras de soll es que los espacios porosos de la soll están ocluidos por la fracción no carbonatada, que resultó ser mayor que en las muestras de franka en la prueba de residuo insoluble en ácidos. the nature of the stone, soll identified by quarry owners and obtained for testing was confirmed to be soll $(7.03 \%$ insoluble residues) and the bajda and safra samples were confirmed as franka (2.07\% and $2.29 \%$ average insoluble residues respectively). The ranges obtained to date for franka and soll are $1-3 \%$ and 3-14\% respectively (13).

Results of the physical and mechanical testing of these samples confirmed previous research in these areas. Thus, soll samples exhibited the highest average dry compressive strength when compared to bajda and safra (franka) samples as shown in Table 1. On the other hand, the uniaxial compressive strengths of the latter two, both being franka, were comparable. These results adhere to previous research work by Cachia (17) where soll (32.9N/ $\mathrm{mm}^{2}$ av. compressive strength) was found to be stronger than franka in compression. A possible reason for a greater compressive strength in the soll samples is that the pore spaces in the soll are occluded by the noncarbonate fraction, which was found to be greater than that in franka samples in the acid-insoluble residue test.

Tabla 1 / Table 1

Resumen de los resultados obtenidos en la prueba de compresión uniaxial Summary of results obtained for the uniaxial compression test

\begin{tabular}{|c|c|c|c|c|}
\hline \multirow{2}{*}{$\begin{array}{l}\text { Tipo de piedra / } \\
\text { stone type }\end{array}$} & \multicolumn{4}{|c|}{$\begin{array}{c}\text { Resistencia a la compresión uniaxial en seco }\left(\mathrm{N} / \mathrm{mm}^{2}\right) / \\
\text { dry uniaxial compressive strength }\left(\mathrm{N} / \mathrm{mm}^{2}\right)\end{array}$} \\
\hline & $\begin{array}{l}\text { Valor promedio / } \\
\text { average value }\end{array}$ & $\begin{array}{l}\text { Valor mínimo / } \\
\text { minimum value }\end{array}$ & $\begin{array}{l}\text { Valor máximo / } \\
\text { maximum value }\end{array}$ & $\begin{array}{l}\text { Desviación típica / } \\
\text { standard deviation }\end{array}$ \\
\hline soll & 30.16 & 27.90 & 32.33 & 1.68 \\
\hline bajda (franka) & 19.85 & 17.29 & 21.85 & 2.03 \\
\hline safra (franka) & 21.30 & 20.35 & 21.94 & 0.59 \\
\hline
\end{tabular}

Las muestras de soll resultaron tener una porosidad total $(29,8 \%)$ inferior a las muestras de ambas frankas, la bajda $(30,4 \%)$ y la safra $(35,6 \%)$. No hay mucha diferencia entre estos resultados y los obtenidos por Farrugia (18) con doce muestras distintas de piedra, en las que la porosidad total de las muestras de soll $(32,2 \%)$ fue inferior a la de las muestras de franka $(40,7 \%)$. Fitzner y otros (19) también observaron que la porosidad de una muestra de soll (33\%) era inferior a la de una muestra de franka $(34,8 \%)$ durante los ensayos de porosidad realizados a 14 muestras de piedra, en los que obtuvieron resultados entre el $32 \%$ y el $40 \%$.

En la Figura 1 se ofrecen los resultados de la porosimetría. El radio de los poros de los tres tipos de caliza globigerina inferior varía entre 0,001 y $6 \mu \mathrm{m}$. No es posible
Soll samples were found to have a lower overall porosity (29.8\%) when compared to bajda (franka) samples (30.4\%) and safra (franka) samples (35.6\%). These results compare well to those obtained by Farrugia (18) on twelve different stone samples of different types, where the total porosity of the soll samples (32.2\%) was found to be less than that of the franka samples (40.7\%). Fitzner et al. (19) also found that the porosity of one soll (33\%) sample was less than that of a franka sample (34.8\%); porosity tests were carried out on 14 stone samples and ranged from $32 \%$ to $40 \%$.

Porosimetry results are given in Figure 1. Pore radii of the three types of Lower Globigerina Limestone lie in the range 0.001-6 $\mu \mathrm{m}$. Lower pore sizes are not detectable. 
detectar poros de menor tamaño. La gran mayoría de poros en las muestras de soll se encuentra en las franjas de $0,1-0,6 \mu \mathrm{m}$ y de $1-2 \mu \mathrm{m}$, mientras que para las muestras de franka (bajda y safra), la mayoría de los poros se encuentran en la franja de 2-4 $\mathrm{mm}$, lo que indica que la soll tiene un porcentaje mayor de poros pequeños que la caliza globigerina franka. Tanto para la franka como para la soll se obtuvo una distribución bimodal. El radio medio de los poros de las muestras de soll fue de 0,99 $\mu \mathrm{m}$, mientras que el de las muestras de bajda fue equivalente a $3,76 \mu \mathrm{m}$ y el radio medio de los poros de las muestras de safra fue de 3,78 $\mu \mathrm{m}$. Respecto a los poros grandes con radios entre 2 y $6 \mu \mathrm{m}$, el mayor volumen relativo $(53,51 \%)$ se encontró en las muestras de bajda (fran$k a$ ), seguidas de las de safra (franka, volumen relativo del $51,57 \%$ ). El volumen relativo de los poros de mayor tamaño presentes en soll fue del $2,81 \%$.
The maximum concentration of the distribution of pores for soll samples lies in the ranges of 0.1-0.6 $\mu \mathrm{m}$ and 1-2 $\mu \mathrm{m}$, whereas for the bajda (franka) and safra (franka) samples this lies in the range 2-4 $\mu \mathrm{m}$ implying that soll has a higher percentage of small pores when compared to franka globigerina limestone. For both franka and soll, a bimodal distribution was obtained. The average pore radius of the soll samples was found to be $0.99 \mu \mathrm{m}$. That of bajda samples was found to be equivalent to $3.76 \mu \mathrm{m}$ and the average pore radius of safra samples equal to $3.78 \mu \mathrm{m}$. Regarding large pores having radii in the range of 2-6 $\mu \mathrm{m}$, bajda (franka) samples were found to have the maximum percentage relative volume equal to $53.51 \%$, followed by safra (franka) samples having a relative volume of $51.57 \%$. The relative volume of the larger pores present in soll amounted to $2.81 \%$.

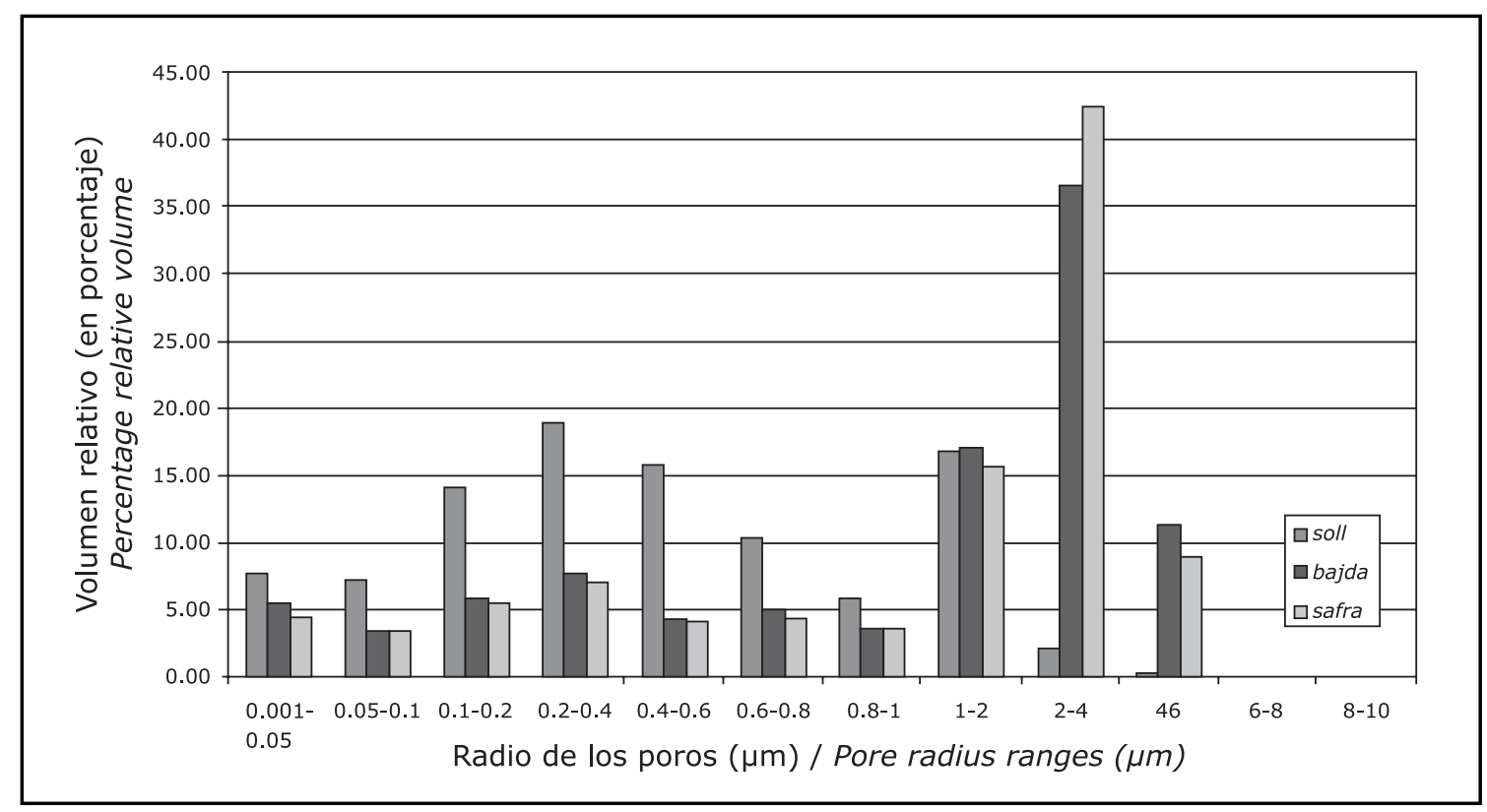

Figura 1. Resultados de la porosimetría realizada a bajda, safra y soll no meteorizadas.

Figure 1. Porosimetry results for unweathered bajda, safra and soll.

Los resultados de absorción de agua por capilaridad indicaron un comportamiento muy similar de las muestras de franka (tanto bajda como safra) entre sí pero muy distinto respecto a las muestras de soll (Figura 2). Las muestras de bajda (franka) tenían un coeficiente mayor de subida de agua por capilaridad $\left(2,08 \times 10^{-3} \mathrm{~g} / \mathrm{cm}^{2} \mathrm{~s}^{0,5}\right)$ que las muestras de safra (franka; $1,96 \times 10^{-3} \mathrm{~g} / \mathrm{cm}^{2} \mathrm{~s}^{0,5}$ ), pero en ambos casos el coeficiente de absorción de agua por capilaridad fue muy superior al obtenido con las muestras de soll $\left(1,63 \times 10^{-3} \mathrm{~g} / \mathrm{cm}^{2} \mathrm{~s}^{0,5}\right)$. Estos resultados confirman las observaciones realizadas anteriormente por Cachia (17), en las que la subida por capilaridad en las muestras de soll era muy baja en comparación con las muestras de franka.
Results for water absorption by capillarity showed that franka samples (both bajda and safra) behaved very similarly to one another and very differently from the soll samples (Figure 2). Bajda (franka) samples had a higher coefficient of water rise by capillarity $\left(2.08 \times 10^{-3} \mathrm{~g} / \mathrm{cm}^{2} \mathrm{~s}^{0,5}\right)$ than safra (franka) samples $1.96 \times 10^{-3} \mathrm{~g} / \mathrm{cm}^{2} \mathrm{~s}^{0,5}$ ), but in both cases, the coefficient of absorption of water by capiIlarity was much greater than that obtained for the soll samples $\left(1.63 \times 10^{-3} \mathrm{~g} / \mathrm{cm}^{2} \mathrm{~s}^{0,5}\right)$. Said results confirm previous observations by Cachia (17) where the rate of capillarity rise in soll samples was observed to be very low when compared to the franka samples. 


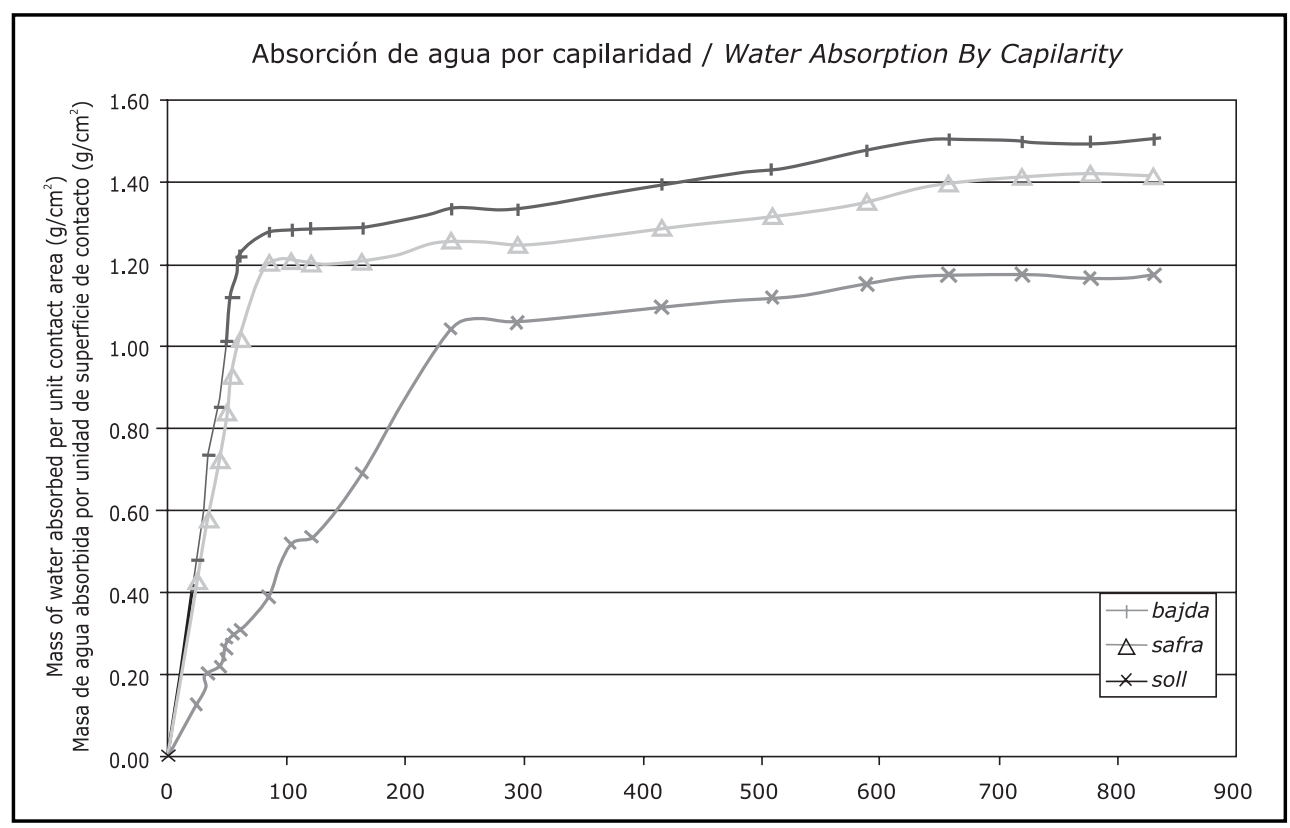

Figura 2. Resultados de absorción media de agua por capilaridad en las muestras no meteorizadas ni tratadas.

Figure 2. Results of average water absorption by capillarity of unweathered, untreated samples.

\subsection{Meteorización de piedras tratadas y no trata- das}

En las Figuras 3-5 se muestra la evolución de la cristalización del $\mathrm{Na}_{2} \mathrm{SO}_{4}$ en soll, bajda y safra. En ellas puede verse el flujo de la disolución salina a través de la superficie de la piedra que queda al descubierto. En concreto, se muestra $\frac{\Delta W(\mathrm{~g})}{s\left(\mathrm{~cm}^{2}\right)}$ en función de $\mathrm{t}(\mathrm{h})$, donde:

$\Delta \mathrm{W}=$ pérdida de peso del conjunto: probeta, disolución y vaso de precipitados (debida a la evaporación del agua de la disolución salina a través de la superficie de la piedra que queda al descubierto)

$\mathrm{s}=$ superficie de la piedra que queda al descubierto

$\mathrm{t}=$ tiempo

Los datos obtenidos para las probetas de soll (Figura 3) indican que la velocidad de evaporación de la disolución que sube por las probetas tratadas con inhibidor es superior a la de las probetas no tratadas. En la práctica, los inhibidores provocan por tanto un mayor flujo capilar de la disolución salina por los materiales porosos.

Se observó una eficacia más pronunciada del inhibidor $\mathrm{A}$ contra el crecimiento de cristales. La introducción de un grupo fosfato en la estructura molecular parece ser, por consiguiente, un factor importante para aumentar la potencia inhibidora. Esto puede explicarse por el aumento de la densidad de la carga negativa en el seno de la molécula, ocasionando en este caso el aumento de la afinidad de enlace de los cristales. Los datos muestran además que la eficacia del inhibidor A depende ligeramente

\subsection{Weathering of treated and untreated stones}

The trend of the results obtained for $\mathrm{Na}_{2} \mathrm{SO}_{4}$ crystallization tests for soll, bajda and safra is shown by diagrams in Figures 3-5, representing the flow of the saline solution through the exposed surface of the limestone slabs. In particular, $\frac{\Delta W(\mathrm{~g})}{s\left(\mathrm{~cm}^{2}\right)}$ vs $t(h)$ is reported, where:

$\Delta W=$ weight loss of the specimen-solution-beaker system (due to water evaporation from the saline solution through the exposed stone surface)

$s=$ exposed surface area of the slabs.

$t=$ time

The obtained data for soll specimens (Figure 3) show that the evaporation rate of the solution rising through inhibitor-treated specimens is higher than that rising through the non-treated ones. The inhibitors, in practice, thus lead to an improvement of the saline solution capillary flow through the porous materials.

A more pronounced efficiency of inhibitor $A$ toward crystal growth inhibition was observed. The introduction of a phosphate group in the molecular skeleton seems therefore to be an important factor in determining the increase of the inhibitory power. This may be explained by the enhancement of the negative density charge in the molecule, leading, in this case, to an increase in crystal binding affinity. Moreover the data also show a slight dependence on the concentration of the inhibitor A solu- 


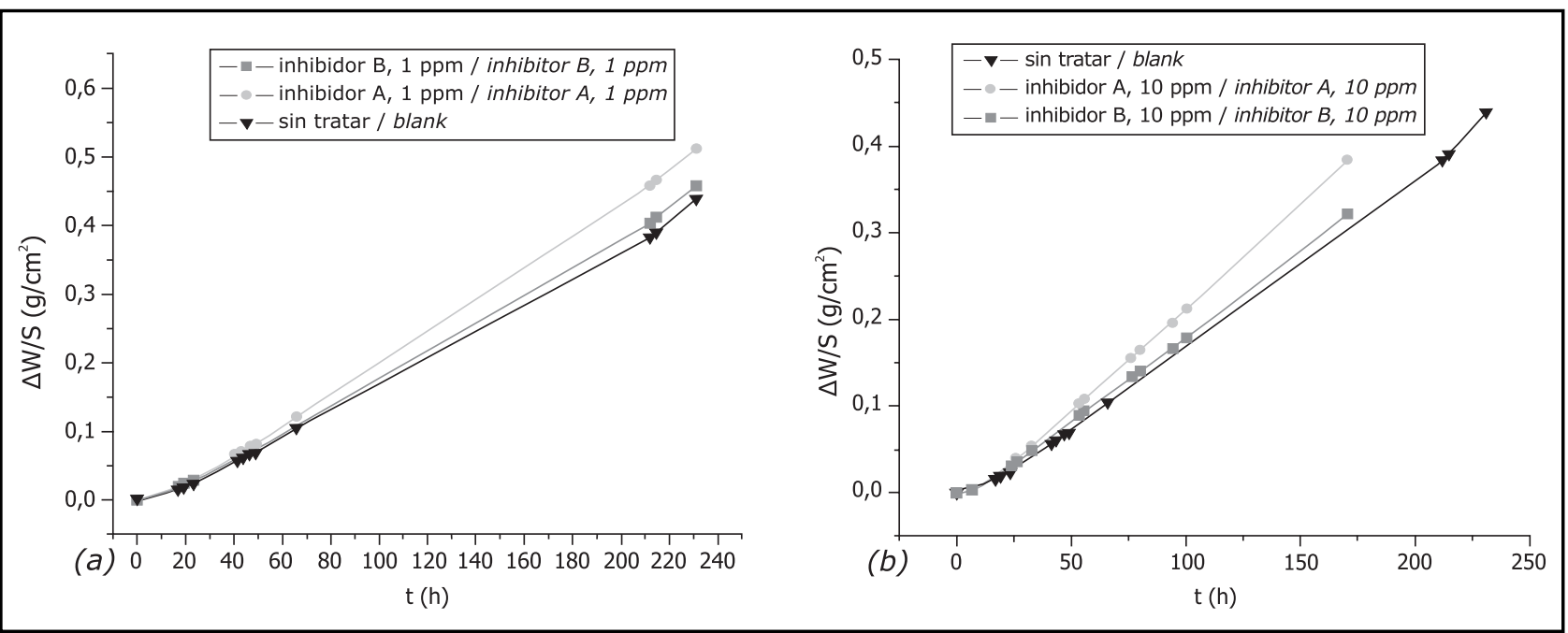

Figura 3. Curvas de evaporación de soll.

Figure 3. Soll evaporation curves.

de la concentración de la disolución. Con tiempos de evaporación más largos, el inhibidor A de 10 ppm tiende a ofrecer mejores resultados que el de $1 \mathrm{ppm}$.

Respecto a las probetas de bajda (Figura 4), se observa nuevamente un efecto ligeramente más pronunciado del inhibidor A fosforilado en comparación con el B. Sin embargo, cuando se usa la solución con concentración de 10 ppm, ambos inhibidores parecen inhibir el crecimiento de cristales de manera eficaz, induciendo a que la cristalización se produzca en la superficie de las probetas y no dentro de los poros. Esto se traduce en la formación de un mayor grado de eflorescencia en la superficie de la piedra (en comparación con la subeflorescencia) en presencia de inhibidores. tion. At longer evaporation times, inhibitor $A$ at 10ppm tends to yield better results than the same inhibitor at 1 ppm.

Regarding bajda specimens (Figure 4), a slightly more pronounced effect of the phosphorylated inhibitor $A$ with respect to $B$ is again observed. When used in $10 \mathrm{ppm}$ concentration solution, both inhibitors seem, however, to be effective towards crystal growth inhibition, helping the crystallization to occur on the surface of the specimens and not within the pores. This translates into the formation of a higher amount of efflorescence on the stone surface (with respect to subefflorescence) in the presence of inhibitors.
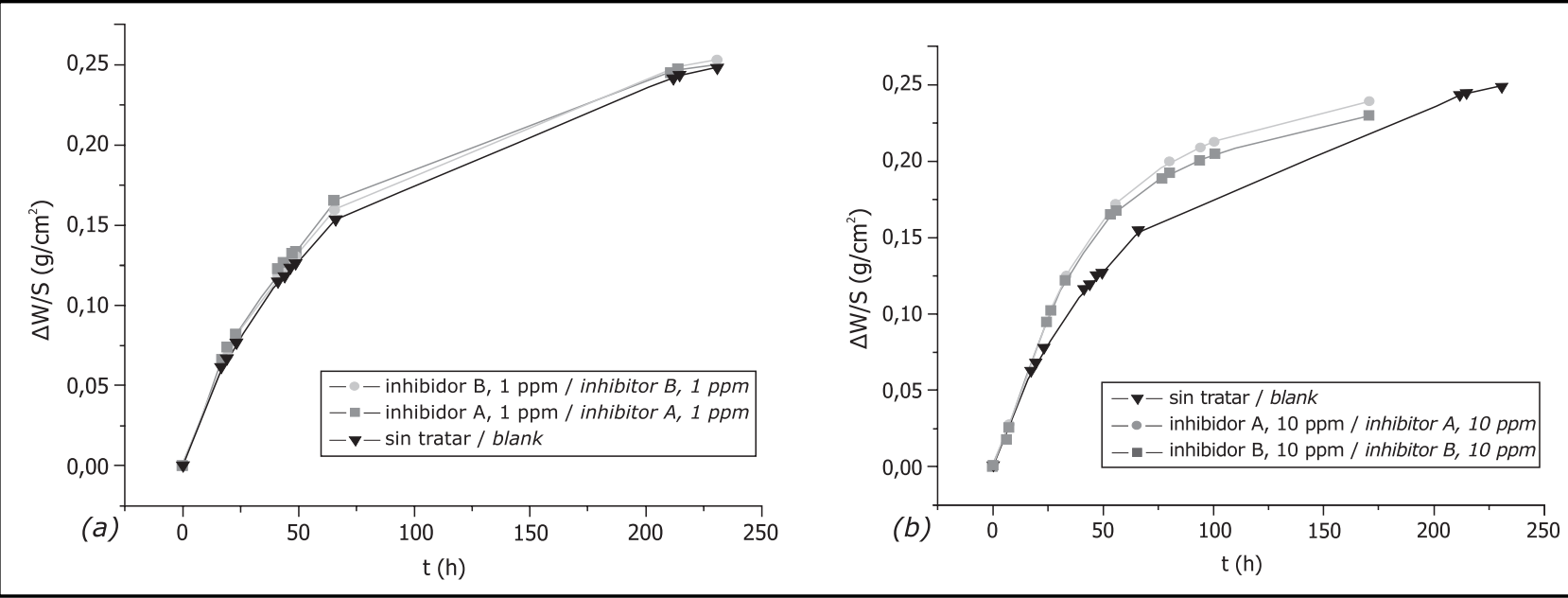

Figura 4. Curvas de evaporación de bajda.

Figure 4. Bajda evaporation curves. 
Los datos obtenidos para las probetas de safra (Figura 5) difieren de los comentados anteriormente, ya que muestran un efecto más pronunciado del inhibidor B (el no fosforilado) en la inhibición del crecimiento de cristales.
The data obtained for safra specimens (Figure 5) differ from those discussed above as they show a more pronounced effect of the inhibitor $B$ (that is the non-phosphorylated one) towards crystal growth inhibition.
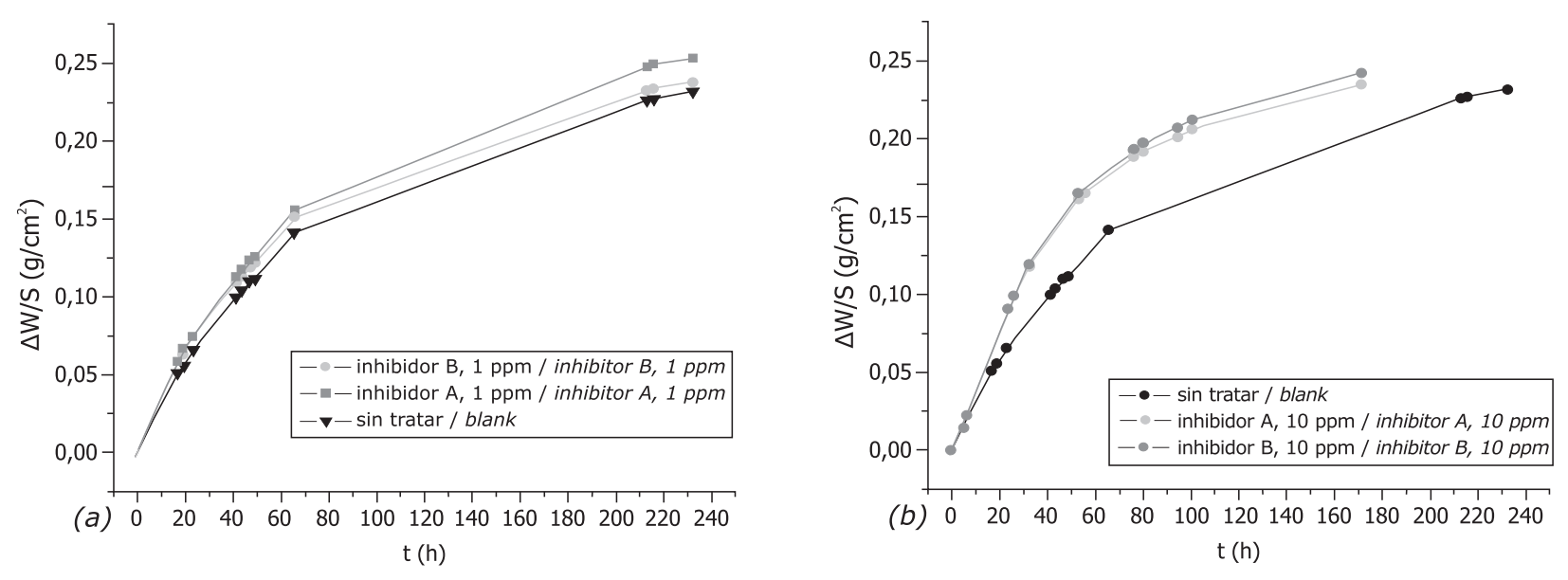

Figura 5. Curvas de evaporación de safra.

Figure 5. Safra evaporation curves.

Esto puede deberse a la combinación de varios factores, entre ellos la distinta composición química de este tipo de globigerina con respecto a la soll y a la bajda. De hecho, en la caliza safra el microanálisis electrónico indicó claramente la presencia de fósforo. Además, la velocidad de evaporación de la disolución que sube por las probetas tratadas con inhibidor es mayor cuanto mayor sea la concentración de la disolución de inhibidor.

La cristalización del $\mathrm{Na}_{2} \mathrm{SO}_{4}$ provocó distintos tipos de daños dependiendo del tipo de piedra (20-22). En el caso de las piedras no tratadas, incluso después de un ciclo de sal, se observó un deterioro más rápido y pronunciado en las muestras de soll que en las de franka. Esto puede estar relacionado con la diferencia en la distribución del tamaño de los poros de los tres tipos de piedra mencionada anteriormente: la soll tiene un mayor porcentaje de pequeños poros, lo que provoca mayores daños causados por la sal. En la soll, se observó la formación de una costra externa, tanto con la aplicación de inhibidores como sin ella. Al quitar la capa exterior pudieron verse subeflorescencias (Figura 6). En la bajda y la safra, los daños se limitaron a una ligera pulverización de la superficie.

Tras las pruebas de cristalización, se pesó el detrito eliminado de la superficie de la soll, previa separación de la sal, y se observó una pérdida menor de material en las probetas tratadas con inhibidor. En concreto, la pérdida de material descendió hasta un $47 \%$ respecto a las muestras no tratadas.
This might be due to the combination of several parameters, among which the different chemical composition of this kind of Globigerina with respect to both soll and bajda. In safra limestone, in fact, electron microanalysis clearly showed the presence of phosphorous. Moreover, the evaporation rate of the solution rising through inhibitor-treated specimens is higher when higher concentrations of the inhibitor solutions are used.

$\mathrm{Na}_{2} \mathrm{SO}_{4}$ crystallization caused different types of damage depending on the stone type (20-22). For the untreated stones, even after one salt cycle, faster and more pronounced deterioration was observed for the soll samples than for the franka ones. This can be correlated to the difference in pore size distribution of the three stone types, reported previously, with soll having a higher percentage of small pores, leading to greater salt damage. In soll, the formation of an external crust was observed, both with and without the application of inhibitors; pushing the outer layer out, subefflorescences were visible (Figure 6). In bajda and safra, damage consisted only in some powdering of the surface.

After the crystallization tests, the debris brushed from the soll surface was weighed, after separating it from the salt, and a smaller loss of material for inhibitor-treated specimens was observed. In particular such loss registered a decrease of up to $47 \%$, when compared to untreated samples. 
(a)

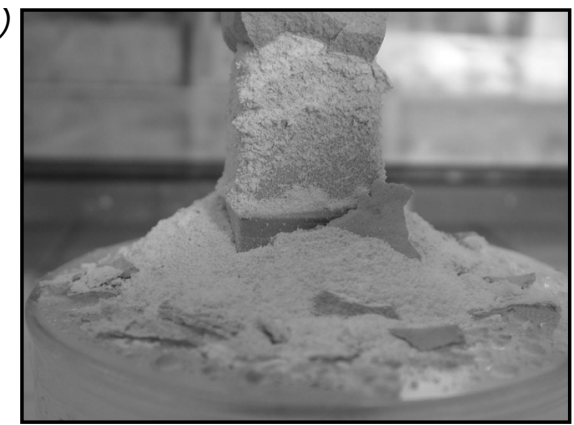

(b)

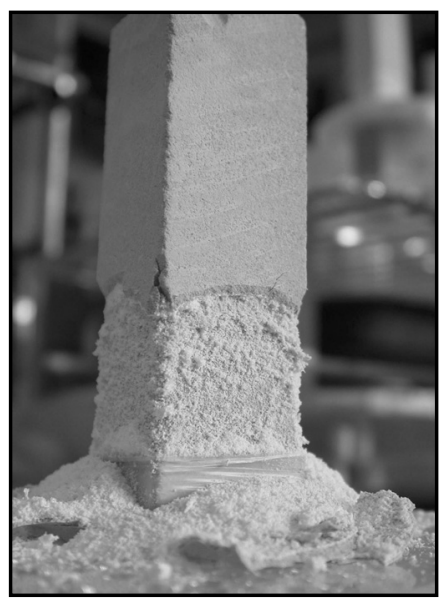

Figura 6. Muestras de soll: (a) no tratada y (b) tratada.

Figure 6. Weathered (a) non-treated and (b) treated soll samples.

\section{CONCLUSIONES}

De los resultados anteriores puede concluirse que ambos inhibidores (el A y el B) resultaron eficaces contra el crecimiento de cristales de sulfato sódico en los tres tipos de caliza globigerina. En las muestras de soll tratadas con inhibidor se observó además una reducción del característico desprendimiento de costras. Excepto en el caso de las muestras de safra, el compuesto fosforilado parece tener una acción más pronunciada que el no fosforilado. Con estos alentadores resultados se llegó a la conclusión de que los inhibidores de sales pueden ser una forma útil de tratar la piedra infestada de estos compuestos. Se continúan las investigaciones en este sentido. Actualmente se están realizando experimentos para estudiar el efecto de los inhibidores en la cristalización del $\mathrm{NaCl}$ en la caliza globigerina.

\section{AGRADECIMIENTOS}

Agradecemos profundamente la ayuda del arquitecto Gaetano Zammit (Universidad de Malta) por proporcionar los bloques de piedra en la cantera y por realizar la prueba del residuo insoluble en ácido. Los autores también desean dar las gracias al profesor Aldo Taticchi (Universidad de Perusa) por sus valiosas sugerencias y comentarios; y a la doctora Maria Cristina Ginnasi y a la señora Margherita Franceschini (Universidad de Perusa) por su ayuda con los experimentos de cristalización y el análisis de los datos.

\section{CONCLUSIONS}

In conclusion, both inhibitors ( $A$ and $B$ ) show effectiveness toward sodium sulphate crystal growth in all three types of Globigerina Limestone. Moreover, in the inhibitor-treated soll samples a reduction of the characteristic crust detachment was observed. Except in the case of safra samples, the phosphorylated compound seems to have a more pronounced activity with respect to the nonphosphorylated one. These encouraging results have led to the preliminary conclusion that salt inhibitors can be a useful means of treating salt-infested stone. Further research in this respect is now continuing; experiments testing the effect of the inhibitors on $\mathrm{NaCl}$ crystallization in Globigerina Limestone are currently in progress.

\section{ACKNOWLEDGEMENTS}

The assistance of Arch. Gaetano Zammit (University of Malta) in acquiring the quarry stone blocks and for carrying out the acid insoluble residue test is gratefully acknowledged. The authors also wish to thank Prof. Aldo Taticchi (University of Perugia) for helpful discussion and comments, and Dr. Maria Cristina Ginnasi and Miss Margherita Franceschini (University of Perugia) for their assistance in crystallization experiments and data analysis. 


\section{BIBLIOGRAFÍA / BIBLIOGRAPHY}

(1) Cassar, J.: "Comparing visual and geochemical classification of limestone types: the Maltese Globigerina Limestone". 10th International Congress on Deterioration and Conservation of Stone, 27 June - 2 July, 2004, Stockholm, Sweden (2004), pp. 569-577.

(2) Buckley, H. E.: Crystal Growth, Chapman \& Hall, London, (1952).

(3) Öner, M.,. Dogan, Ö., Öner, G.: "The influence of polyelectrolytes architecture on calcium sulphate dehydrate growth retardation". Journal of Crystal Growth, Vol. 186 (1998), pp. 427-437.

(4) Van der Leeden, M.C., Van Rosmalen, G.M.: "Adsorption behaviour of polyelectrolytes on barium sulphate crystals". Journal of colloid and interface science, Vol. 171 (1995), pp. 142-149.

(5) Marrocchi, A., Taticchi, A., Santarelli, M.L., Minuti, L., Broggi, A.: "Inibitori della crescita di cristalli di solfato di sodio in materiali lapidei. 1." Science and Technology for Cultural Heritage, Istituti Editoriali e Poligrafici Internazionali, Pisa-Roma, no 1/2 (2006), pp. 101-108.

(6) Marrocchi, A., Taticchi, A., Santarelli, M.L., Minuti, L., Broggi, A., Garibaldi, V.: "Acidi organici quali inibitori della cristallizzazione di sali nei materiali lapidei. 2." Science and Technology for Cultural Heritage, Istituti Editoriali e Poligrafici Internazionali, Pisa-Roma, no. 1/2, (2006), pp. 109-114.

(7) Marrocchi, A., Taticchi, A., Santarelli, M.L., Broggi, A., Minuti, L., Librando, V.: "Acidi organici quali inibitori della cristallizzazione del cloruro di sodio e di miscele cloruro di sodio-solfato di sodio nei materiali lapidei porosi. 3." Science and Technology for Cultural Heritage, Istituti Editoriali e Poligrafici Internazionali, Pisa-Roma, no 1/2 (2006), pp. 115-123.

(8) Marrocchi, A., Santarelli, M.L., Taticchi, A., Broggi, A., Minuti, L.: "New products for the inhibition of salt efflorescences in masonries". Proc. Workshop Argamassas de reboco para paredes antigas sujeitas à acção de sais solúveis (Lisbon, LNEC, 14-15 February 2005). National Laboratory for Civil Engineering (LNEC), Lisbon (2006)

(9) Rodriguez-Navarro, C., Linares-Fernandez, L., Doehne, E., Sebastian, E.: "Effects of ferrocyanide ions on NaCl crystallization in porous stone". Journal of Crystal Growth, Vol. 243 (2002), pp. 503-516.

(10) Rodriguez-Navarro, C., Doehne, E., Sebastian, E.: "Influencing crystallization damage in porous materials through the use of surfactants: experimental results using sodium dodecylsulfate and cetyldimethylbenzylammonium chloride". Langmuir, Vol. 16 (2000), pp. 947-954 (11) Selwitz, C., Doehne, E.: "The evaluation of crystallization modifiers for controlling salt damage to limestone". Journal of Cultural Heritage, Vol. 3 (2002), pp. 205-216.

(12) Houck, J., Scherer, G.W.: "Controlling stress from salt crystallization". Proceedings of 16th European Conf. Fracture, Alexandropoulis, Greece, (2006). In print.

(13) Cassar, J., Vella, A. J.: "Methodology to identify badly weathering limestone using geochemistry: case study on the Lower Globigerina Limestone of the Maltese islands". Quarterly Journal of Engineering Geology and Hydrogeology, Vol. 36 (2003), pp. 85-96.

(14) BS EN 1926: 1999: Natural Stone Test Methods: Determination of Compressive Strengths.

(15) Normal 4/80: Misura della Distribuzione del Volume dei Pori in Funzione del loro Diametro, (1980).

(16) UNI 10859:2000 (replaces Normal 11/85): Materiali lapidei naturali ed artificiali - Determinazione dell'assorbimento dell'acqua per capillarità.

(17) Cachia J.: "The mechanical and physical properties of the Globigerina Limestone as used in local masonry construction". B.E.\&A. dissertation (unpublished), University of Malta, (1985).

(18) Farrugia, P.: "Porosity and related properties of local building stone". B.E.\&A. dissertation (unpublished), University of Malta, (1993). (19) Fitzner, B., Heinrichs, K., Volker, M.: "Model for salt weathering at Maltese Globigerina Limestones". Origin, Mechanisms and Effects of Salt on Degradation of Monuments in Marine and Continental Environments. Proceedings, European Commission Research Workshop on Protection and Conservation of the European Cultural Heritage, Bari, Italy. Research Report, 4 (1995), pp. 331-344.

(20) Rossi-Manaresi, R., Tucci, A.: "Pore structure and the disruptive or cementing effect of salt crystallization in various types of stone". Studies in Conservation, Vol. 36 (1991), pp. 53-58

(21) Vanzini, M., Lucarelli, L.: "How particle size distribution, surface area and pore size relate". Proceedings of the Workshop: Porosità e Porosimetria: importanza, implicazioni e sviluppo nel settore dei beni culturali, ICCROM, Rome, (2000), Ed. Ernesto Borrelli.

(22) Vanzini, M., Lucarelli, L.: "Porosity Investigation by mercury porosimetry: theory, applications and interpretations". Proceedings of the Workshop: Porosità e Porosimetria: importanza, implicazioni e sviluppo nel settore dei beni culturali, ICCROM, Rome, (2000), Ed. Ernesto Borrelli. 